ISSN : $2302-1590$

E-ISSN: $2460-190 \mathrm{X}$

ECONOMICA

Journal of Economic and Economic Education Vol.1 No.1 (78-85)

\title{
IMPORTANCE PERFORMANCE ANALYSIS (IPA) DIMENSI KUALITAS PELAYAN JASA RUMAH SAKIT SELASIH TERHADAP KEPUASAN PASIEN
}

\author{
Rizky Natassia \\ Dosen Program Studi Pendidikan Ekonomi STKIP- PGRI Sumbar \\ Jl. Gunung Pangilun No.1, Padang Sumatera Barat \\ Email: Rizkynatassia@gmail.com
}

Submitted: 2012.09.15 Reviewed: 2012.09.30 Accepted: 2012.10.18

http://dx.doi.org/10.22202/economica.2012.v1.i1.107

\begin{abstract}
This research is intended to measure hospitalized patients' satisfaction toward dimension of Selasih Hospital service quality. It covers realibility, reponsiveness, assurance, emphaty, and tangibility. The researcher used close questions in collecting the primary data. She collected the data by using non probability sampling through convenience sampling. There were 170 patients taken as samples, they were divided into three classes; I, II and III. The used method of analysis is; the importance performance analysis, it is acknowledged that laboratorium check-up, doctor visit, immediate treatment; accurate and immediate check-up result, ineffective sophisticated equipment are not satisfactory to the customers. To ease these problems, the hospital management is expected to enhance medical staff competence and knowledge. The doctors, nurses and staffs commitment should also be enhanced so that they will always serve the patients well without distiguishing their classes. At last but not least, this hospital is suggested to cooperate with other hospitals which have adequate equipments.
\end{abstract}

\begin{abstract}
Abstrak
Penelitian ini dimaksudkan untuk mengukur kepuasan pasien rawat inap 'terhadap dimensi kualitas pelayanan Rumah Sakit Selasih. Ini mencakup realibility, reponsiveness, jaminan, empati, dan berwujud. peneliti menggunakan pertanyaan dekat dalam mengumpulkan data primer. Dia mengumpulkan data dengan menggunakan non probability sampling melalui convenience sampling. Ada 170 pasien diambil sebagai sampel, mereka dibagi menjadi tiga kelas; I, II dan III. Metode yang digunakan analisis adalah; analisis kinerja pentingnya, diakui bahwa laboratorium check-up, dokter kunjungan, pengobatan segera; check-up hasil yang akurat dan cepat, peralatan canggih tidak efektif tidak memuaskan kepada pelanggan. Untuk meringankan masalah ini, manajemen rumah sakit diharapkan dapat meningkatkan kompetensi staf medis dan pengetahuan. Para dokter, perawat dan staf komitmen juga harus ditingkatkan sehingga mereka akan selalu melayani pasien dengan baik tanpa distiguishing kelas mereka. Akhirnya namun tidak sedikit, rumah sakit ini disarankan untuk bekerja sama dengan rumah sakit lain yang memiliki peralatan yang memadai.
\end{abstract}

Keywords : Service quality dimension, patient satisfaction, the importance performance analysis 


\section{PENDAHULUAN}

Memenuhi dan memuaskan kebutuhan pelanggan secara umum adalah salah satu upaya untuk menarik pelanggan. Pelanggan yang merasa sangat puas lebih sukar untuk merubah pilihannya. Situasi konsumsi dan kepuasan pelanggan yang tinggi akan tercipta apabila penyedia jasa mampu menciptakan pengalaman yang tak terlupakan bagi pelanggan ( Stanton, 1998).

Pada dasarnya pengertian kepuasan merupakan perbedaan antara jasa yang diharapkan (expected service) dan jasa yang dipersepsikan (perceived service). Dengan kata lain kepuasan adalah tingkat dimana seseorang setelah membandingkan kinerja pelayanan atau hasil yang ia rasakan dibandingkan dengan harapan. Misalnya seorang pasien yang mengharapkan pelayanan pemeriksaan, pengobatan, dan perawatan yang cepat dan tepat dari rumah sakit (Supranto, 2002)

Pelanggan yang puas adalah pelanggan yang akan berbagi kepuasan dengan penyedia jasa yaitu, dengan menceritakan pengalaman yang dirasakan kepada pelanggan lain berkenaan dengan jasa yang diberikan oleh penyedia jasa. Sehingga hal ini akan menjadi referensi bagi penyedia jasa untuk pelanggan yang lain. Oleh karena itu, baik pelanggan maupun penyedia jasa akan sama-sama diuntungkan apabila kepuasan terjadi. Dengan melihat hubungan ini, jelaslah bahwa kepuasan pelanggan harus menjadi salah satu tujuan dari setiap perusahaan.

Untuk meningkatkan kepuasan pelanggan penyedia jasa harus memperhatikan kinerja pelayanan yang dipengaruhi oleh lima dimensi kualitas pelayanan (Parasuraman, Zeithaml,dan Bery ; 1991) yaitu :

- Kehandalan ( reliability)

- Daya tanggap (responsiveness)

- Jaminan (assurance)

- Empati (emphaty)

- Bukti fisik (tangibles)

Dimensi yang pertama adalah kehandalan (realibility), berkaitan dengan kemampuan perusahaan untuk memberikan layanan yang akurat sejak pertama kali tanpa membuat kesalahan apapun dalam penyampaian jasanya sesuai dengan waktu yang disepakati. Sebuah rumah sakit dikatakan handal kalau proses penerimaan pasien dilakukan dengan cepat, prosedur pengadministrasian serta pembayaran yang praktis, tindakan yang cepat dan tepat terhadap pemeriksaan dan pengobatan, pemeriksaan laboratorium, kunjungan dokter, serta perawatan dijalankan dengan tepat ; penerimaan hasil pemeriksaan secara tepat dan cepat ( Supranto, 2002).

Dimensi kedua adalah daya tanggap (responsiveness) berkaitan dengan kesediaan dan kemampuan karyawan untuk membantu pelanggan dan merespon permintaan mereka, serta menginformasikan kapan jasa akan diberikan. Rumah sakit dikatakan memiliki daya tanggap apabila petugas selalu siap sedia untuk membantu pasien pemberian informasi yang jelas kepada pasien, sistem pelayanan yang tidak berbelit-belit dan cepat tanggap terhadap keluhan pasien ( Supranto, 2002).

Dimensi yang ketiga adalah jaminan (assurance) berkenaan dengan perilaku karyawan yang mampu menumbuhkan kepercayaan pelanggan terhadap perusahaan, dan menciptakan rasa aman bagi pelanggan. Rumah sakit dikatakan memiliki jaminan apabila pelayanan yang diberikan rumah sakit kepada pasien disertai dengan keahlian dokter dalam menetapkan diagnosis, keterampilan dan pengetahuan personel medis, serta jaminan dan kepercayaan terhadap pelayanan yang diberikan (Supranto, 2002).

Dimensi yang keempat adalah empati (empathy) berkenaan dengan kemampuan perusahaan untuk memahami masalah pelanggan dan bertindak demi pelanggan. Rumah sakit dikatakan memiliki dimensi empati apabila peduli terhadap keluhan pasien, kepedulian terhadap kebutuhan dan keinginan pasien, tidak pilih-pilih dalam memberikan pelayanan kepada semua pasien dan kesimpatikan dokter dan petugas terhadap pasien (Supranto, 2002).

Dimensi yang terakhir adalah bukti fisik (tangibles), berkaitan dengan daya tarik fasilitas fisik, perlengkapan, dan material yang digunakan perusahaan, serta penampilan karyawan. Rumah sakit memiliki bukti fisik yang baik apabila kondisi interior dan eksterior ruangan ditata secara menarik, kondisi kenyamanan dan kebersihan gedung, kerapihan dan kebersihan petugas, dan kecanggihan peralatan yang ada (Supranto, 2002).

Berdasarkan uraian dari latar belakang diatas, maka permasalahan yang dibahas dalam penelitian ini adalah, bagaimana analisis importance performance analysis dimensidimensi kualitas jasa (reliability, 
responsiveness, assurance, emphaty, dan tangibles) terhadap kepuasan pasien Rumah Sakit Selasih ?

\section{LANDASAN TEORI}

\section{A. Pengertian Jasa}

Menurut Rangkuty (2003) jasa merupakan pemberian suatu kinerja atau tindakan tidak kasat mata dari satu pihak kepada pihak lain. Pada umumnya jasa diproduksi dan dikonsumsi secara bersamaan, dimana interaksi antara pemberi jasa dan pemerima jasa mempengaruhi hasil jasa tersebut.

Berdasarkan uraian diatas dapat dijelaskan bahwa jasa pada dasarnya merupakan suatu yang tidak berwujud, yang dapat memenuhi kebutuhan dan keinginan konsumennya. Dan dalam memproduksi suatu jasa, dapat digunakan produk fisik sebagai pendukung penjualan jasa tersebut. Selain itu pada jasa pembeliannya tidak menyebabkan perpindahan kepemilikan.

Secara garis besar, klasifikasi jasa dapat dilakukan berdasarkan tujuh kriteria pokok (Evans dan Berman ;1990 dalam Tjiptono ; 2005 ) :

1. Segmen pasar

Berdasarkan segmen pasar, jasa dapat dibedakan menjadi jasa yang ditujukan pada konsumen akhir (misalnya taksi, asuransi jiwa, katering, jasa tabungan, dan pendidikan) dan jasa bagi konsumen organisasional (misalnya biro periklanan, jasa akuntansi dan perpajakan, dan jasa konsultasi manajemen)

\section{Tingkat keberwujudan}

Kriteria ini berhubungan dengan tingkat keterlibatan produk fisik dengan konsumen. Berdasarkan kriteria ini jasa dapat dibedakan menjadi tiga macam yaitu :

\section{a. Ranted goods service}

Dalam tipe ini, konsumen menyewa dan menggunakan produk tertentu berdasarkan tarif yang disepakati selama jangka waktu spesifik. Konsumen hanya menggunakan produk tersebut, karena kepemilikannya tetap di tangan pihak perusahaan yang menyewakannya. Contohnya penyewaan mobil, videogames, villa, apartemen.

b. Owned goods service

Pada tipe ini, produk-produk yang dimiliki konsumen direparasi, dikembangkan atau ditingkatkan untuk kerjanya, atau dipelihara/dirawat oleh perusahaan jasa. Jenis jasa ini juga mencakup perubahan bentuk pada produk yang dimiliki konsumen. Contohnya meliputi jasa reparasi (arloji, mobil, sepeda, motor, komputer, kulkas, dan lain-lain), pencucian mobil, perawatan rumput padang golf.

c. Non goods services

Karakteristik khusus pada jenis ini adalah jasa personal bersifat intangible (tidak berbentuk produk fisik) ditawarkan kepada para pelanggan. Contoh penyedia jasa tipe ini antara lain sopir, dosen, penata rias, baby sitter, pemandu wisata, dan lain-lain.

Dalam kaitannya dengan aspek pemasaran, secara umum dapat dikatakan bahwa semakin tidak berwujud sebuah jasa, maka semakin sedikit kesamaan antara pemasaran jasa dan pemasaran barang berwujud. Pada non goods services, misalnya kinerja hanya dapat dinilai setelah jasa disampaikan dan konsistensi kinerja bersangkutan sulit dijaga. Sebaliknya rented goods services dan owned goods services dapat dipasarkan dengan cara-cara serupa dengan pemasaran barang berwujud (produk fisik), karena tipe jasa ini memerlukan barangbarang fisik dan lebih bersifat tangible.

3. Keterampilan penyedia jasa.

Berdasarkan tingkat keterampilan penyedia jasa terdapat dua tipe pokok jasa. Pertama professional services (seperti dosen, konsultan manajemen, konsultan hukum, dokter, perawat, psikolog, dan lain-lain). Non professional services (seperti jasa supir taksi, tukang parkir, pengantar surat, dan lain-lain).

4. Tujuan organisasi

Berdasarkan tujuan organisasi, jasa dapat diklasifikasikan menjadi commercial services atau profit services (misalnya jasa penerbangan, bank biro iklan, hotel, dan lainlain) dan non profit services (misalnya sekolah, yayasan dana bantuan, panti asuhan, meseum, dan lain-lain).

\section{Regulasi}

Dari aspek regulasi, jasa dapat dibagi menjadi regulated services (misalnya angkutan umum, media massa, perbankan, dan lain-lain) dan non regulated services (misalnya kost, asrama, kantin sekolah, dan lain-lain). 
6. Tingkat intensitas karyawan.

Berdasarkan tingkat intensitas karyawan (keterlibatan tenaga kerja), jasa dapat dikelompokkan menjadi dua macam yaitu : equipment based sevices (misalnya binatu, mesin ATM, jasa sambungan telepon interlokal dan internasional dan lin-lain) dan people based services (misalnya pelatih sepak bola, satpam, bidan, dokter anak dan lain-lain). 7. Tingkat kontak penyedia jasa dan pelanggan.

Berdasarkan tingkat kontak ini,secara umum jasa dapat dikelompokkan menjadi high contact services (misalnya dokter, penata rambut, dan lain-lain) dan low contact services (misalnya jasa telekomunikasi, jasa PLN, dan lain-lain).

\section{B. Konsep Kualitas Jasa}

Lewis dan Booms (1983) dalam Tjiptono (2005) mendefenisikan kualitas jasa sebagai ukuran seberapa bagus tingkat layanan yang diberikan mampu sesuai dengan ekspektasi pelanggan. Berdasarkan defenisi ini kualitas jasa bisa diwujudkan melalui pemenuhan kebutuhan dan keinginan pelanggan serta ketepatan penyampaiannya untuk mengimbangi harapan pelanggan.

Dengan demikian ada 2 (dua) faktor utama yang mempengaruhi kualitas jasa: jasa yang diharapkan (expected service) dan jasa yang dirasakan/dipersepesikan (perceived service) Parasuraman, Zeithaml,dan Bery (1991). Apabila perceived service sesuai dengan expected service, maka kualitas jasa bersangkutan akan dipersepsikan baik atau dipersepsikan sebagai kualitas ideal. Sebaliknya apabila perceived service lebih jelek dibanding expected service, maka kualitas jasa dipersepsikan negatif atau buruk. Oleh karena baik atau tidaknya kualitas jasa tergantung pada kemampuan penyedia jasa dalam memenuhi harapan pelanggannya secara konsisten.

\section{Dimensi Kualitas Jasa}

$$
\begin{aligned}
& \text { Melalui serangkaian penelitian } \\
& \text { terhadap berbagai macam industri jasa, } \\
& \text { Parasuraman, Zeithaml,dan Bery (1991) } \\
& \text { berhasil mengidentifikasi lima dimensi kualitas } \\
& \text { jasa: } \\
& \text { a. Reliabilitas (reliability), berkaitan dengan } \\
& \text { kemampuan perusahaan untuk } \\
& \text { memberikan layanan yang akurat sejak } \\
& \text { pertama kali tanpa membuat kesalahan }
\end{aligned}
$$

apapun dan menyampaikan jasanya sesuai dengan waktu yang disepakati.

b. Daya tanggap (responssiveness), berkenaan dengan kesediaan dan kemampuan para karyawan untuk membantu para pelanggan dan merespons permintaan mereka, serta menginformasikan kapan jasa akan diberikan dan kemudian memberikan jasa secara cepat.

c. Jaminan (assurance), yakni perilaku para karyawan mampu menumbuhkan kepercayaan pelanggan terhadap perusahaan dan perusahaan bisa menciptkan rasa aman bagi para pelanggannya. Jaminan juga berarti bahwa para karyawan selalu bersikap sopan dan menguasai pengetahuan dan keterampilan yang dibutuhkan untuk menangani setiap pertanyaan atau masalah pelanggan.

d. Empati (empathy), berarti perusahaan memahami masalah para pelanggannya dan bertindak demi kepentingan pelanggan, serta memberikan perhatian personal kepada para pelanggan dan memiliki jam operasi yang nyaman.

e. Bukti fisik (tangibles), berkenaan dengan daya tarik fasilitas fisik, perlengkapan, dan material yang digunakan perusahaan, serta penampilan karyawan.

\section{Konsep Kepuasan Pelanggan}

Kata kepuasan (satisfaction) berasal dari bahasa latin "satis" artinya cukup baik, memadai, dan "facio" artinya melakukan atau membuat. Kepuasan bisa diartikan sebagai "upaya pemenuhan sesuatu" atau "membuat sesuatu memadai".

Menurut Kotler dalam Widiyanto (2003), hanya perusahaan yang berwawasan pelanggan yang akan bertahan, karena mereka bisa memberikan nilai yang lebih baik dari pada pesaingnya kepada pelanggan sasaran. Sehingga kepuasan pelanggan dapat didefenisikan sebagai berikut :

"Kepuasan pelanggan adalah tingkat perasaan seseorang setelah membandingkan kinerja atau hasil yang dirasakan dibandingkan dengan harapan".

\section{E. Model SERVQUAL}

Model kualitas jasa yang paling populer dan hingga kini banyak dijadikan acuan dalam riset manajemen dan pemasaran jasa adalah model SERVQUAL (singkatan dari 
service quality) yang dikembangkan oleh Parasuraman, Zetihaml, dan Berry (1991).

Model SERVQUAL didasarkan pada asumsi bahwa konsumen membandingkan kinerja jasa pada atribut-atribut relevan dengan standar ideal/sempurna untuk masing-masing atribut jasa. Menurut Rangkuty (2003) bila kinerja sesuai dengan atau melebihi standar, maka persepsi atas kualitas jasa keseluruhan akan positif dan sebaliknya. Dengan kata lain, model ini menganalisis gap antara dua variabel pokok, yakni jasa yang diharapkan (expected service) dan jasa yang dipersepsikan (perceived service).Dengan menggunakan model ini mereka mengidentifikasi 5 gap yang menyebabkan kegagalan penyampaian jasa ( Rangkuty, 2003). Gap tersebut antara lain adalah sebagai berikut :

1. Gap antara harapan konsumen dan persepsi manajemen (knowledge gap).

Pihak manajemen suatu perusahaan tidak selalu dapat memahami atau merasakan apa yang diinginkan oleh konsumen secara tepat. Manajemen tidak mengetahui bagaimana suatu jasa didesain dan jasa pendukung diinginkan.

2. Gap antara persepsi manajemen terhadap harapan konsumen dan spesifikasi kualitas jasa (standards gap)

Kadangkala manajemen mampu memahami secara tepat keinginan konsumen, tetapi mereka tidak menyusun suatu standar kerja tertentu yang jelas. Dikarenakan oleh tiga faktor yaitu: tidak adanya komitmen total manajemen terhadap kualitas jasa, kekurangan sumber daya atau kelebihan permintaan.

3. Gap antara spesifikasi kualitas jasa dan penyampaian jasa (delivery gap)

Adapun beberapa penyebab terjadinya gap ini misalnya, karyawan kurang terlatih, beban kerja melampaui batas, tidak dapat memenuhi standar kerja atau bahkan tidak mau memenuhi standar kerja yang telah ditetapkan.

4. Gap antara penyampaian jasa dan komunikasi eksternal (communications gap)

Seringkali harapan konsumen dipengaruhi oleh iklan-iklan dan janji-janji yang dibuat perusahaan, resikonya perusahaan tidak memenuhinya.

5. Gap antara jasa yang dirasakan dan jasa yang diharapkan (service gap)
Gap ini terjadi apabila konsumen mengukur kerja/prestasi perusahaan dengan cara yang berlainan atau bisa juga keliru mempersepsikan kualitas jasa tersebut.

\section{METODE PENELITIAN}

Populasi yang diambil dalam penelitian ini adalah pasien rawat inap kelas Rumah Sakit Selasih yang dirawat minimal 1 x 24 jam. Adapun rawat inap kelas yang dijadikan sebagai populasi terdiri dari pasien rawat inap kelas 1, pasien rawat inap kelas 2 dan pasien rawat inap kelas 3 .

Ukuran sampel ditetapkan berdasarkan atas alat analisis yang digunakan. Maka jumlah sampel yang diisyaratkan adalah paling sedikit lima kali jumlah variabel bebas, penelitian ini menggunakan lima variabel bebas dengan 34 item pertanyaan sehingga jumlah sampel yang diambil adalah sebesar 170 responden (Hair, 1998). Pengambilan sampel dilakukan dengan cara non-probability dengan pendekatan convenience sample.

Data dalam penelitian ini menggunakan data primer yang dikumpulkan dengan field survey yaitu dengan mengajukan daftar pertanyaan berupa kuisioner kepada responden.

Adapun variabel yang dipakai dalam penelitian ini adalah variabel independen (variabel bebas) yaitu dimensi kualitas pelayanan yang meliputi reliability, responsiveness, assurance, emphaty, dan tangibels yang disimbolkan dengan $\mathrm{X}_{1}, \mathrm{X}_{2}, \mathrm{X}_{3}, \mathrm{X}_{4}$, dan $\mathrm{X}_{5}$. Variabel dependen (variabel terikat) yaitu tingkat kepuasan pasien yang disimbolkan dengan $Y$.

Metoda analisis yang digunakan adalah Importance Performance Analysis. Merupakan alat analisis yang digunakan utnuk menentukan skor penilaian kinerja perusahaan jika dibandingkan dengan skor tingkat kepentingan bagi pelanggan. Formula yang digunakan adalah sebagai berikut (Rangkuty, 2003) :

$$
100 \%
$$$$
\text { Tki }=\underline{X i} x
$$

\section{Yi}

Dimana :

Tki $=$ Indeks kesesuaian responden

$\mathrm{Xi}=$ Skor penilaian kinerja Rumah Sakit Selasih

$\mathrm{Yi}=$ Skor penilaian kepentingan pasien Rumah Sakit Selasih 
Sedangkan untuk mengetahui skor penilaian rata-rata tingkat kinerja perusahaan dan skor rata-rata tingkat kepentingan pelanggan yang berguna untuk menentukan prioritas peningkatan item-item yang mempengaruhi kepuasan pasien digunakan diagram kartesius ( Supranto, 2002) dengan rumus sebagai berikut :

$$
\begin{array}{r}
\bar{x}=\sum x i \\
y=\frac{\sum y i}{n}
\end{array}
$$

Dimana :

$\mathrm{x}=$ Skor rata-rata tingkat kinerja pelayanan Rumah Sakit Selasih

$\overline{\mathrm{y}}=$ Skor rata-rata tingkat kepentingan konsumen

$\mathrm{n}=$ Jumlah responden Selanjutnya item-item yang mempengaruhi kepuasan pasien akan dijabarkan dan dibagi menjadi empat bagian ke dalam digaram kartesius seperti pada gambar 3.1 berikut :

Harapan
\begin{tabular}{|l|l} 
Perioritas & Pertahankan Prestasi \\
Utama & (B) \\
\hline (A) & \\
Prioritas Rendah & Berlebihan \\
(C) & (D) \\
\hline
\end{tabular}

Pengalaman

Sumber : Supranto (2002)

\section{Gambar 1. Diagram Kartesius}

\section{Keterangan :}

Simbol A artinya, menunjukkan item yang dianggap mempengaruhi kepuasan pasien termasuk unsur-unsur jasa yang dianggap sangat penting, namun pihak manajemen Rumah Sakit Selasih belum melaksanakannya sesuai dengan keinginan pasien sehingga mengecewakan atau tidak memuaskan pasien.

Simbol B artinya, menunjukkan unsur jasa pokok yang telah berhasil dilaksanakan Rumah Sakit Selasih untuk itu wajib dipertahankan. Dianggap sangat penting dan sangat memuaskan.

Simbol C artinya, menunjukkan beberapa item yang kurang penting pengaruhnya bagi pasien, sedangkan pelaksanaannya dilakukan biasa-biasa saja oleh pihak Rumah Sakit Selasih.

Simbol D artinya, menunjukkan item yang dianggap kurang penting di dalam mempengaruhi kepuasan pelanggan namun pelaksaanaannya dilakukan secara berlebihan oleh perusahaan. Dianggap kurang penting tetapi sangat memuaskan.

\section{PEMBAHASAN}

\section{A. Importance Performance Analysis}

Kuadran A menunjukkan item yang dianggap sangat penting bagi pasien namun pihak manajemen Rumah Sakit Selasih belum melaksanakannya. Adapun item yang termasuk pada kuadaran ini adalah pemeriksaan laboratorium, kunjungan dokter, serta perawatan yang dijalankan dengan cepat; penerimaan hasil pemeriksaan secara cepat dan tepat, kecanggihan peralatan yang ada.Pemeriksaan laboratorium, kunjungan dokter, serta perawatan yang dijalankan dengan cepat sangat berpengaruh terhadap jadwal pelaksanaan yang lain, apabila terhadi keterlambatan maka hal ini akan berpengaruh tidak baik pada pasien, seperti keterlambatan pemeriksaan laboratorium akan berpengaruh terhadap jam makan pasien, sehingga waktu makan obat pun dapat terganggu.

Oleh karena itu setiap kegiatan dalam pelayanan kesehatan khususnya dalam bidang keperawatan selalu dilaksanakan dengan disiplin, mulai dari jadwal untuk memandikan pasien, mengganti sprei, memberikan obat, waktu makan, waktu istirahat, jam berkunjung samapai dengan jam kunjungan dokter dan waktu pemeriksaan laboratorium akan 
dilaksanakan sesuai jadwal yang sudah ditetapkan.Selain dari pada itu kecanggihan peralatan yang ada dapat dijadikan sebagai salah satu sarana pendukung dalam penentuan diagnosis serta peralatan yang lebih canggih dalam melaksanakan tindakan medis, membuat banyak tindakan medis menjadi lebih mudah untuk dikerjakan, sehingga hal ini akan meminimalkan resiko yang akan terjadi disamping itu hasil yang diperoleh akan lebih akurat.

Disamping itu untuk menganalisis diagnosis penyakit seorang pasien, sering diperlukan suatu pemeriksaan seperti laboratorium, radiologi, dan pemeriksaan pendukung lainnya, dimana pasien dan dokter sangat menginginkan jawaban hasil pemeriksaan tersebut dengan cepat dan tepat. Kesalahan serta keterlambatan hasil pemeriksaan sangat mempengaruhi kecepatan dan ketepatan pengobatan terhadap pasien, sehingga kecepatan dan ketepatan hasil pemeriksaan dapat digunakan sebagai pilihan utama dalam hal mutu pelayanan yang dapat diterima konsumen atau pasien.

Item yang berada pada Kuadran B menunjukkan unsur jasa pokok yang telah berhasil dilaksanakan Rumah Sakit Selasih untuk itu wajib dipertahankan. Pasien menganggap unsur jasa yang diberikan sangat penting dan sangat memuaskan.Item yang berada pada kuadran B berjumlah 7 item dari jumlah keseluruhan sebanyak 20 item. Item yang berada pada kuadran ini meliputi pelayanan penerimaan pasien yang cepat, kesigapan petugas untuk membantu pasien, pemberian informasi secara jelas dan mudah dimengerti, keahlian dokter dalam menetapkan diagnosis, keterampilan dan pengetahuan personel medis, jaminan keamanan dan kepercayaan terhadap pelayanan, serta kerapihan dan kebersihan petugas.

Item yang berada pada kuadran $\mathrm{C}$ menunjukkan beberapa item yang kurang penting pengaruhnya bagi pasien, sedangkan pelaksanaannya dilakukan biasa-biasa saja oleh pihak Rumah Sakit Selasih. Item yang berada paling banyak pada kuadran ini adalah dimensi empati ( emphaty) yang terdiri dari 3 item yang meliputi peduli terhadap keluhan pasien, peduli terhadap kebutuhan dan keinginan pasien, dan kesimpatikan dokter dan petugas sedangkan item yang paling sedikit berada pada kuadaran ini terdiri dari dimensi kehandalan (reliability), daya tanggap (responsiveness), dan bukti fisik (tangibles) yang meliputi prosedur pengadministrasian serta pembayaran yang praktis, tindakan yang cepat dan tepat terhadap pemeriksaan dan pengobatan, system pelayanan yang tidak berbelit-belit, desain interior dan eksterior ruangan, kebersihan dan kenyamanan gedung.

Kuadran D menunjukkan item yang dianggap kurang penting di dalam mempengaruhi kepuasan pelanggan namun pelaksaanaannya dilakukan secara berlebihan oleh perusahaan dan dianggap kurang penting tetapi sangat memuaskan oleh pasien. Item yang termasuk pada kudran ini adalah memberikan reaksi yang cepat tanggap terhadap keluhan pasien, dan memberikan pelayanan terhadap semua pasien tanpa pilihpilih.

Apabila ditinjau secara keseluruhan berdasarkan item-item yang terdapat pada diagram kartesius maka dapat disimpulkan bahwa dimensi yang berada pada kuadaran A meliputi dimensi kehandalan (reliability) dengan nilai rata-rata kinerja (pengalaman) sebesar 4,09 dan nilai rata-rata harapan sebesar 4,67. Hal ini mengindikasikan bahwa kemampuan rumah sakit dalam melaksanakan jasa yang dijanjikan dengan terpercaya dan akurat masih perlu perbaikan atau pihak manajemen masih perlu berkonsentrasi pada dimensi ini.

Sedangkan pada kuadaran B dimensi yang termasuk pada kuadran ini adalah dimensi daya tanggap (responsiveness) yang memiliki nilai rata-rata kinerja (pengalaman) sebesar 4,28 dan nilai rata-rata harapan sebesar 4,70. Sedangkan pada dimensi jaminan (assurance) memiliki nilai rata-rata kinerja (pengalaman) sebesar 4,34 dan nilai rata-rata harapan sebesar 4,76. Hal ini berarti, bahwa kemampuan rumah sakit untuk membantu pasien dalam memberikan jasa pelayanan sesuai dengan harapan pasien atau dengan kata lain kinerja (pengalaman) yang telah dilakukan oleh rumah sakit telah sesuai dengan keinginan pasien. Begitu juga dengan kesopanan dan pengetahuan karyawan serta kemampuannya untuk menimbulkan kepercayaan dan keyakinan pasien sesuai dengan yang diharapkan oleh pasien.

Dimensi yang termasuk pada kuadran $\mathrm{C}$ adalah dimensi empati (emphaty) yang memiliki nilai rata-rata kinerja (pengalaman) sebesar 4,11 dan nilai rata-rata harapan sebesar 4,59. Sedangkan pada dimensi bukti fisik 
(tangibles) memiliki nilai rata-rata kinerja (pengalaman) sebesar 4,13 dan nilai rata-rata harapan sebesar 4,63. Ini menunjukkan bahwa, harapan pasien akan kepedulian dan kesediaan untuk peduli atau memberikan perhatian pribadi terhadap pasien terletak dibawah ratarata, begitu juga dengan kemampuan rumah sakit dalam penampilan fisik, peralatan, personel dan materi komunikasi. Hal ini berarti pasien menganggap kedua dimensi ini kurang penting, kemudian pihak manajemen rumah sakit juga biasa-biasa saja.

\section{KESIMPULAN}

1. Pada hasil Importance Performance Analysis dapat diketahui bahwa pada kuadran A item yang termasuk pada kuadaran ini adalah pemeriksaan laboratorium, kunjungan dokter, serta perawatan yang dijalankan dengan cepat; penerimaan hasil pemeriksaan secara cepat dan tepat serta kecanggihan peralatan yang ada. Pada kuadran B item yang termasuk pada kuadran ini meliputi pelayanan penerimaan pasien yang cepat, kesigapan petugas untuk membantu pasien, pemberian informasi secara jelas dan mudah dimengerti, keahlian dokter dalam menetapkan diagnosis, keterampilan dan pengetahuan personel medis, jaminan keamanan dan kepercayaan terhadap pelayanan, kerapihan dan kebersihan petugas. Pada kuadaran $\mathrm{C}$ item yang termasuk pada kudran ini adalah prosedur pengadministrasian serta pembayaran yang praktis, tindakan yang cepat dan tepat terhadap pemeriksaan dan pengobatan, system pelayanan yang tidak berbelit-belit, peduli terhadap keluhan pasien, peduli terhadap kebutuhan dan keinginan pasien, kesimpatikan dokter dan petugas, desain interior dan eksterior ruangan, kebersihan dan kenyamanan gedung. Pada kuadran terakhir yaitu kuadaran D item yang terdapat pada kuadran ini meliputi memberikan rekasi yang cepat tanggap terhadap keluhan pasien, memberikan pelayanan terhadap semua pasien tanpa pilih-pilih.

2. Berdasarkan hasil analisis skor rata-rata dapat disimpulkan bahwa yang menjadi alasan utama pasien memilih rumah sakit selasih sebagai tempat perawatan adalah, karena factor dimensi jaminan (assurance). Oleh karena itu pihak manajemen rumah sakit harus memperhatikan dimensi ini karena yang diinginkan pasien dalam memilih sebuah rumah sakit adalah faktor jaminan terhadap jasa yang akan mereka terima. Adapun atribut yang termasuk dalam dimensi ini adalah keahlian dokter dalam menetapkan diagnosis, keterampilan dan pengetahuan personel medis, serta jaminan keamanan dan kepercayaan terhadap pelayanan.

\section{DAFTAR PUSTAKA}

\subsection{2/economica.2012.v1.i1.107}

Gujarati, Damador.1997.Dasar-dasar Ekonometrika. Penerbit: PT Gramedia, Jakarta.

Hair, Anderson, Tatham, dan Blac. 1998. Multi Variate Data Analysis. Fifth Edition, International Inc, Prentice Hall.

Rangkuty, Fredy. 2003. Measuring Customer Satisfaction: Gaining Customer Relationship Strategy, Penerbit: PT Gramedia Pustaka Utama, Jakarta.

Singgih, Santoso. 2005. Menguasai Statistik di Era Informasi dengan SPSS 12, Penerbit: PT. Elex Media Komputindo, Jakarta.

Stanton, J. William. 1998. Prinsip Pemasaran, Edisi Kelima, Jakarta, Erlangga.

Supranto, J. 2002. Pengukuran Tingkat Kepuasan Pelanggan, Edisi Revisi 7 Penerbit: Rineka Pustaka, Jakarta.

Tjiptono, Fandy. 2005. Service, Quality, and Satisfaction, Penerbit: Andi, Yogyakarta.

Widiyanto, A. 2003. Pengukuran Kesenjangan Harapan Pelanggan dan Kinerja Jasa Perawatan Perlatan PT. X. Palembang : Jurnal Manajemen dan Bisnis No. 1 Juli 2003.

Zeithaml, Parasuraman dan Bery, 1991, Delivering Quality Service, The Free Press, Macmilland, Inc. New York. 